\title{
CROSSREACTIVITY AS A FACTOR IN THE IMMUNE RESPONSE TO SALMONELLA TYPHIMURIUM IN CBA AND BALB/C MICE
}

\author{
P. H. WOOLEY* AND A. EBRINGER $\dagger$ \\ Immunology Unit, Departments of ${ }^{*}$ Microbiology and $†$ Biochemistry, \\ Queen Elizabeth College, London W8 7 AH
}

ResistanCE to infection by Salmonella spp. involves cellular (Plant and Glynn, 1974) and humoral immune responses (Di Pauli, 1972). Differences in delayed hypersensitivity permit the classification of animals into susceptible and resistant strains (Vas, Roy and Robson, 1973) whilst differences in antibody response allow classification into high- and low-responder strains (McDevitt and Sela, 1965).

Plant and Glynn (1974) calculated the LD50 of S. typhimurium strain C5 in six different strains of mice after subcutaneous injection. Strains of mice could easily be separated into those sensitive to less than $10^{2}$ and those resistant to more than $10^{5}$ micro-organisms. The most susceptible were BALB/C mice, which had an LD50 of less than $10^{1}$, whilst the most resistant mice belonged to the CBA strain, which had an LD50 of $10^{7}$. The explanation for this difference is at the moment unclear.

Crossreactivity between human tissue and bacterial antigens is thought to be responsible for the development of rheumatic fever after infection with group-A $\beta$-haemolytic streptococci (Kaplan, Meyeserian and Kushner, 1961), though antistreptococcal antibodies have not produced cardiac lesions in experimental animals. Similarly, susceptibility to infection with $S$. typhimurium in mice may be due to partial tolerance of the pathogen caused by crossreactivity to a self component (Rowley and Jenkin, 1962).

Previous reports have demonstrated that cellular immune responses to $S$. typhimurium can be linked to the genetic status of the mouse strain (Plant and Glynn, 1974) but a significant antibody increase was not obtained when the animals were inoculated with relatively small doses of live micro-organisms. Antibody responses could not be studied when larger inoculating doses were used because the animals of the susceptible strains died within a few days.

We have studied the antibody response of CBA and BALB/C mice, to large doses of inactivated bacteria, and investigated the crossreaction between the micro-organism and surface antigens of spleen and lymph-node cells obtained from high- and low-responder strains as a possible explanation for the differing antibody responses.

Revised version received 6 May 1979; accepted 16 May 1979.

Correspondence and requests for reprints to Dr A. Ebringer, Department of Biochemistry, Queen Elizabeth College, London W8 7AH. 


\section{MATERIALS AND METHODS}

Animals. Male BALB/C $\left(\mathrm{H}-2^{\mathrm{d}}\right)$ and CBA $\left(\mathrm{H}-2^{\mathrm{k}}\right)$ mice, aged 6-8 weeks, were used in all experiments.

Preparation of micro-organisms. S. typhimurium (Queen Elizabeth College collection, strain B22) was grown overnight in $50 \mathrm{ml}$ of Nutrient Broth (Oxoid) with continuous agitation. Bacteria were separated from the medium by centrifugation at 6000 r.p.m., washed twice with phosphate-buffered saline (PBS) at $p \mathrm{H} 7.2$ and stored at $4^{\circ} \mathrm{C}$. A suspension of $S$. typhimurium $10^{5} / \mathrm{ml}$ in PBS in a petri dish was irradiated at $5 \mathrm{~cm}$ with ultraviolet light (Hanovia UV bacteriocidal lamp, Model 12; peak output at $253 \mathrm{~nm}$ ) for four periods of $45 \mathrm{~min}$. Samples were tested for residual viability after each irradiation. After inactivation (viability less than $0.01 \%$ ), the suspension was adjusted to $10^{9} / \mathrm{ml}$ in PBS, with the aid of Brown opacity tubes (Burroughs Wellcome; Mackie and McCartney, 1953) and used for primary and secondary immunisation.

Immunisation of mice. Mice from both strains were divided into three groups: each comprised a primary-response group of 15 mice, a secondary-response group of 25 mice and a control group of 8 mice. All test mice received an initial intraperitoneal injection of $0.2 \mathrm{ml}$ of the bacterial suspension adjusted to $10^{7}$ organisms $/ \mathrm{ml}$. Fourteen days later, all mice in the primaryresponse group were bled out by axillary exsanguination; mice in the secondary-response group received another intraperitoneal injection of $0.2 \mathrm{ml}$ of bacterial suspension. Secondary-response and control mice were bled out 9 days later; the serum was separated and stored at $-20^{\circ} \mathrm{C}$.

In a second experiment, to test antibody responses after repeated immunisation, $7 \times 10^{8} \mathrm{~S}$. typhimurium in $20 \mathrm{ml}$ of PBS were inactivated with 135000 rad (Cobalt-60 source), then adjusted to Brown opacity 5 with sterile PBS and stored at $4^{\circ} \mathrm{C}$. BALB/C and CBA mice, aged 6 weeks, were each arranged in groups of 30 test and 20 control mice. All test mice were immunised intraperitoneally with $0.2 \mathrm{ml}$ of $S$. typhimurium suspension. Seven days after the first immunisation, three test mice and two control mice from each strain were bled out by axillary exsanguination, and the serum was separated and stored at $-20^{\circ} \mathrm{C}$. All remaining test mice received another injection of $0.2 \mathrm{ml}$ of bacterial suspension. Subsequently, similar weekly injections and bleedings were carried out on test and control mice, until the tenth week, when all sera were assayed for antibody.

Sampling of inocula. During primary immunisation, samples were obtained at random and diluted to 1 in 100 with filtered PBS containing sodium azide $0.05 \%$ (w/v); bacterial counts were then measured with a Coulter Counter (Model 2BI, Coulter Electronics Ltd).

Preparation of rabbit Salmonella typhimurium antiserum. A rabbit was immunised subcutaneously with $S$. typhimurium in Freund's Complete Adjuvant (Difco) and given booster injections of microbial suspension in PBS at six-monthly intervals over two years; it was then bled and the serum was separated and stored in $1-\mathrm{ml}$ ampoules at $-20^{\circ} \mathrm{C}$.

Measurement of antibody activity was by Widal assay (Kaufmann,1954) in which $1 \mathrm{ml}$ of suspension of $S$. typhimurium of density equivalent to Brown opacity 5 was added to $1 \mathrm{ml}$ portions of doubling dilutions of antiserum in PBS, in Dreyer tubes; after incubation for $2 \mathrm{~h}$ at $37^{\circ} \mathrm{C}$ the agglutinating endpoint was read. Each assay run contained unknown as well as known positive and negative sera. When the approximate endpoint had been obtained by doubling dilutions, the assay was repeated with arithmetic dilutions of serum and the highest dilution at which agglutination could be observed was taken as the endpoint.

Crossreactive antigens. Spleen and lymph-node-axillary, inguinal and mesenteric-cell suspensions were prepared from unimmunised normal $\mathrm{CBA}$ and $\mathrm{BALB} / \mathrm{C}$ mice; these suspensions were washed three times with PBS, the cells were counted and parallel CBA and BALB/C suspensions containing equal numbers of cells were prepared.

Cells from both strains were then added to separate $100-\mu$ l portions of rabbit anti-S. typhimurium serum of known titre and incubated for one hour at $37^{\circ} \mathrm{C}$; the cells were then removed by centrifugation at 1000 r.p.m. and the supernatant antiserum was assayed for residual antibody activity.

Estimation of Fc receptor-bearing cells in preparations of spleen. The number of Fc receptorbearing cells in the spleen-cell preparations was measured by the erythrocyte-antibody (EA) rosette technique (Hudson and Hay, 1976). Mouse antiserum to sheep red blood cells (SRBC) 
was prepared by giving outbred mice two intraperitoneal injections of $0.5 \mathrm{ml} \mathrm{SRBC}$ suspension $(1 \% \mathrm{v} / \mathrm{v}) 10$ days apart. The mice were bled out on the 18 th day, and the sera were pooled. The subagglutinating dilution was determined as 1 in 80 by direct light microscopy. Antiserum at this dilution was used to coat a suspension of $\operatorname{SRBC}(1 \% \mathrm{v} / \mathrm{v})$ during continuous agitation for 60 min. This EA preparation was washed three times in PBS before use. Spleen-cell suspensions were prepared exactly as described for the absorption of the rabbit anti-salmonella activity, and adjusted to $5 \times 10^{6}$ cells $/ \mathrm{ml}$.

Results were calculated by the method of Hudson and Hay (1976) and the percentage of Fc receptor-bearing cells in the spleen preparations was determined.

\section{RESULTS}

\section{Bacterial counts in immunisation sample}

During primary immunisation, 10 samples of bacterial suspensions, each of $0.2 \mathrm{ml}$, were counted five times in a Coulter counter. The bacterial count was $1.69 \pm 0.51 \times 10^{7}$ (sample mean $\pm \mathrm{SD}$ ) and the scatter was from $1.11 \times 10^{7}$ to $2 \cdot 25 \times 10^{7}$ per sample.

\section{Antibody titres after primary and secondary immunisation}

The mean antibody titre, as assessed by Widal agglutination, in eight unimmunised CBA mice was $32 \cdot 0 \pm 2 \cdot 3$ (mean \pm SE of the mean) whilst in eight $\mathrm{BALB} / \mathrm{C}$ mice it was $26 \cdot 0 \pm 2 \cdot 9$. This difference in titre between the two strains of unimmunised mice was not statistically significant.

The mean antibody titre, 14 days after primary immunisation, in 15 CBA mice was $58.4 \pm 3.7$ whilst in $15 \mathrm{BALB} / \mathrm{C}$ mice it was $61 \cdot 3 \pm 3.3$. Again the difference in titre between the two strains was not statistically significant.

The mean antibody titre after secondary immunisation in 25 CBA mice was $520 \cdot 8 \pm 14 \cdot 6$, whilst in $25 \mathrm{BALB} / \mathrm{C}$ mice it was $289 \cdot 6 \pm 16 \cdot 7$; this difference is statistically significant $(t=10 \cdot 39, \mathrm{p}<0.001)$.

After secondary immunisation, the titres from all CBA mice exceeded the mean titre obtained for BALB/C mice.

\section{Antibody titres after repeated immunisation}

The mean antibody titres in CBA and BALB/C mice after weekly immunisations over a period of 10 weeks are shown in fig. 1 . The antibody titre was always greater in CBA mice than in BALB/C mice, and this difference became apparent from the second week onwards (week 10,t=7.0, p <0.005).

\section{Crossreactivity experiments}

The results of the absorption experiments with spleen cells are shown in fig. 2. The residual $S$. typhimurium activity of the rabbit antiserum was found to be greater after absorption with CBA spleen cells than with BALB/C spleen cells and this difference is statistically significant $(t$-related statistic $=7 \cdot 460$, 


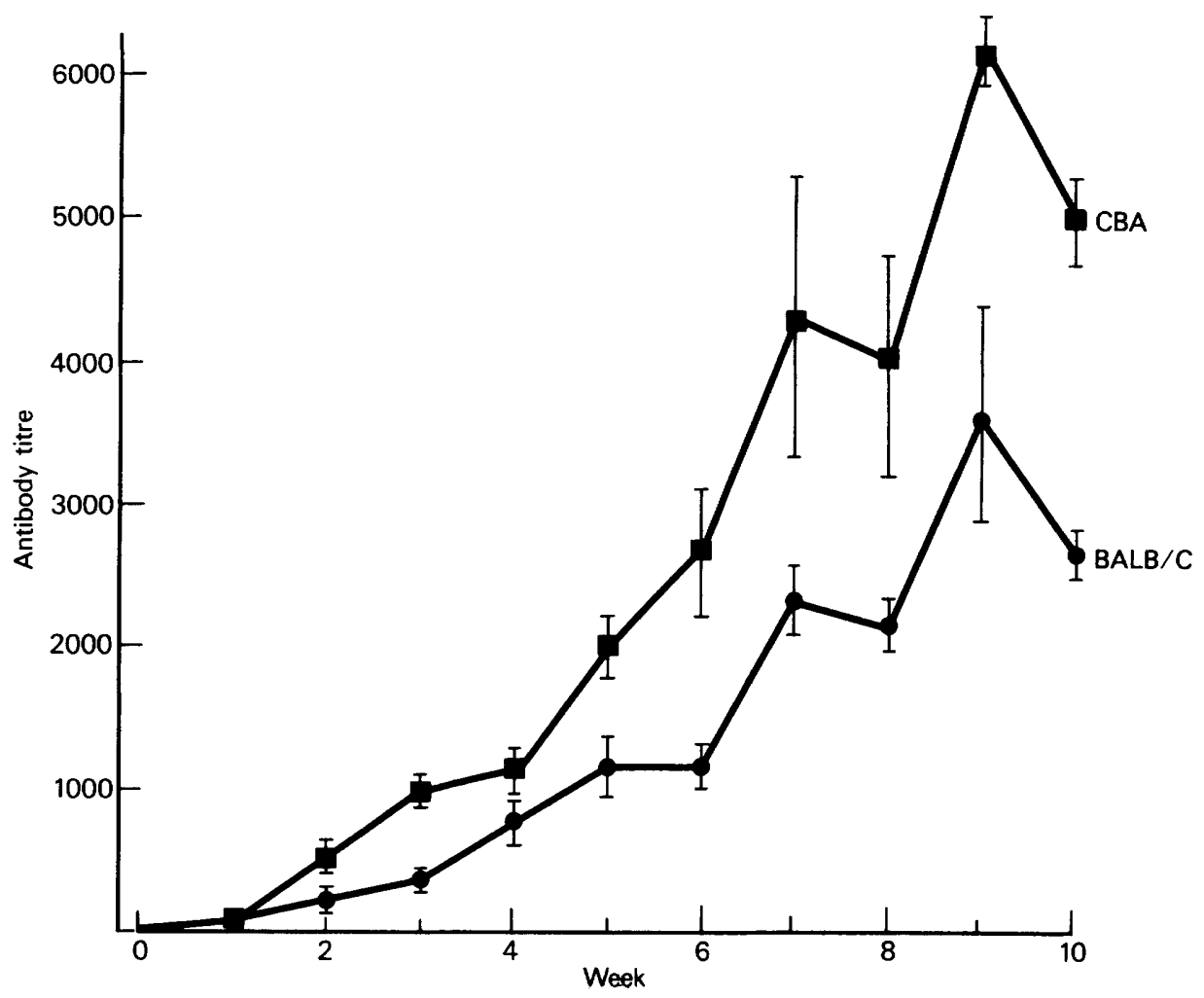

Fig. 1.-Antibody titres in CBA and BALB/C mice after immunisations with inactivated Salmonella typhimurium. Each point represents the mean of estimations in three mice; the bars indicate standard error.

$\mathrm{p}<0.001)$. Furthermore, the mean difference in agglutinating activity after absorption with CBA and BALB/C mouse spleen cells was found to increase with the number of absorbing cells, as shown in fig. 3 ; this correlation is statistically significant $(r=+0.738, \mathrm{p}<0.05)$.

Absorption of rabbit $S$. typhimurium antiserum with lymph-node cells again showed that cells obtained from $B A L B / C$ mice removed more anti-salmonella activity than did cells obtained from CBA mice. The residual Widal titre after absorption with $10^{6} \mathrm{CBA}$ lymph-node cells was 5000 whilst after absorption with $10^{6} \mathrm{BALB} / \mathrm{C}$ lymph-node cells it was 2000 . After absorption with $16.4 \times 10^{6} \mathrm{CBA}$ lymph-node cells, the residual titre was 3000 ; after similar treatment with BALB/C cells it was 1000 .

The frequency of $F c$ receptor-bearing cells in the spleen-cell preparations, as estimated by the sheep red-cell-rosette technique, was found to be similar in CBA and in BALB/C mice: in eight experiments, the mean percentage of Fc-binding cells in the spleen preparations from CBA mice was $49.99 \pm 2.26$ (mean $\pm \mathrm{SE}$ of the mean) and from BALB/C mice was $48 \cdot 46 \pm 1.96$. 


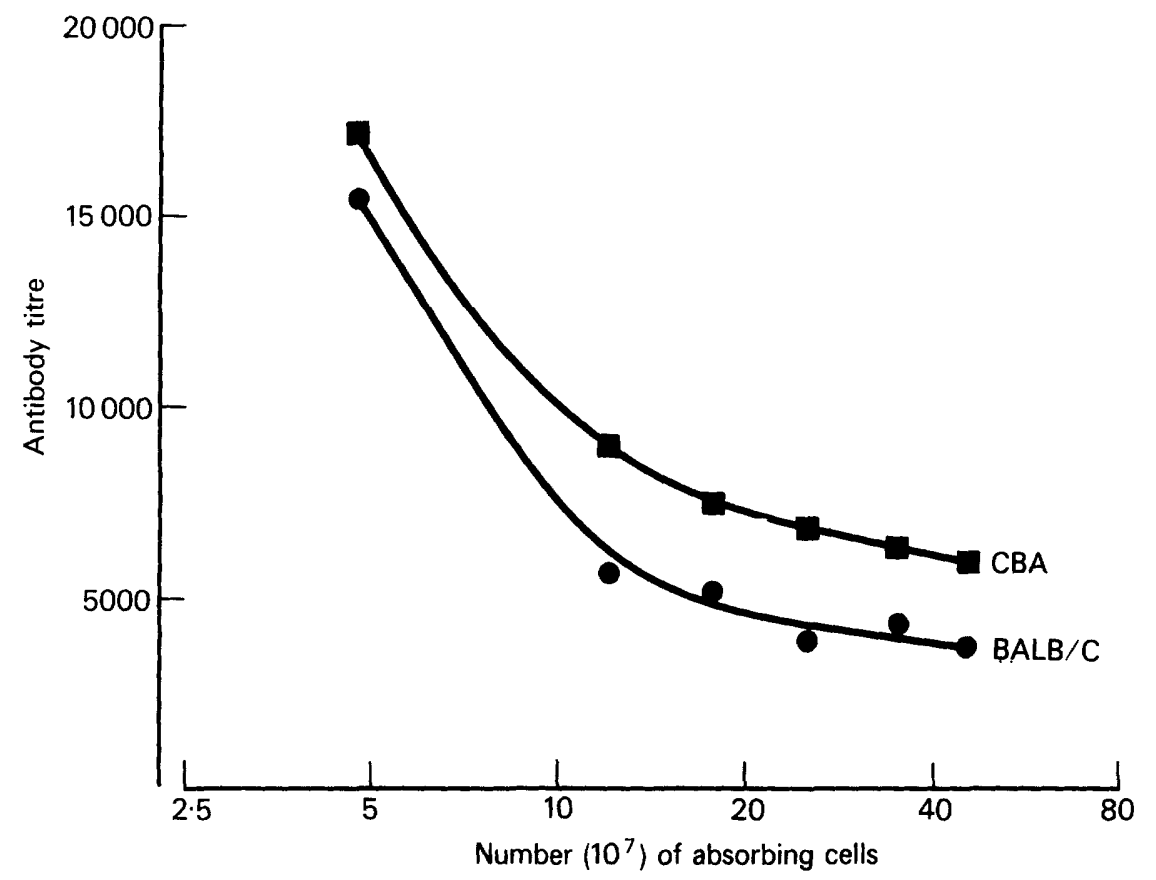

FIG. 2.-Antibody titre in rabbit Salmonella typhimurium antiserum after absorption with CBA or BALB/C spleen cells. Each point is the mean of four estimations. Each absorption was an independent experiment carried out with fresh spleen cells from different CBA or BALB/C mice.

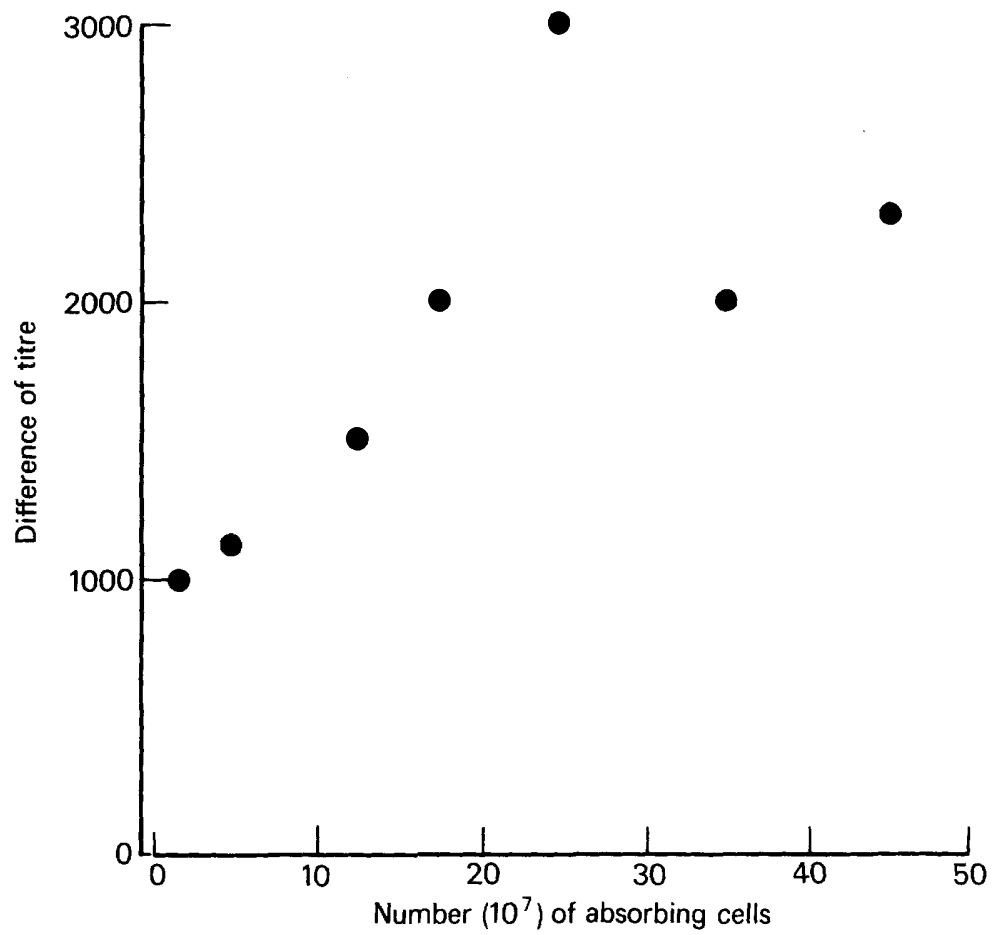

FIG. 3.--Mean difference (=titre of CBA-absorbed serum - titre BALB/C-absorbed serum) in agglutinating activity of rabbit Salmonella typhimurium antiserum after absorption with mouse spleen cells. 


\section{Discussion}

The demonstration that some strains of animals are resistant and others susceptible to infection by a given strain of micro-organism has been known for many years (Lewis and Loomis, 1928; Gowen and Schott, 1933) and several mechanisms have been proposed to explain this phenomenon (Eastwood, 1927). Particular strains of mice that differ in susceptibility to infection by $S$. typhimurium have been known for some time (Gorer and Schütze, 1938) and it has been suggested that genetically determined resistance might operate through the presence of opsonising antibodies which enhance clearance of $S$. typhimurium from the circulation of infected animals (Rowley and Jenkin, 1962). We have shown that higher titres of agglutinating antibodies against $S$. typhimurium are produced by CBA mice than by BALB/C mice and this appears to be inversely related to the infectivity of this micro-organism in different strains of mice (Plant and Glynn, 1974). The differences were not due to variation in the number of micro-organisms injected because this was kept approximately constant, or to the number of Fc receptor-bearing cells because this was similar in both strains of mice.

A possible explanation for these results is provided by the "crosstolerance hypothesis" which suggests that some animals give a low antibody respons because their own tissue antigens crossreact to a greater extent with the bacterial antigens than do those of the more responsive animals (Ebringer 1978). Some evidence in support of this hypothesis has already been propose for the T,G A-L(tyrosine-glutamic acid-alanine-lysine) polymer syste (Ebringer and Davies, 1973), for the ferritin immunogenic system (Deacon ar. Ebringer, 1977), for the HLA-linked disease ankylosing spondylitis (Ebringt et al., 1976) and for the blood-group associated disease rheumatic fever (Ebringer, Welsh and Young, 1976). A similar mechanism of antigenic cross reaction between host and parasite has been proposed as a possible cause 0 pathogenicity in Salmonella infections (Rowley and Jenkin, 1962).

In the study reported here, rabbit antibodies to $S$. typhimurium were absorbed by spleen cells from BALB/C mice to a greater extent than by : equal number of spleen cells from CBA mice and the reduction in antibor activity was related to the number of spleen cells used for each absorptic Similar results were obtained with lymph-node cells.

If crossreactivity between test antigen and self antigen occurs, as suggest ${ }^{\prime}$ by this study, it still does not explain the mechanism whereby differing $b$ reproducible antibody responses are characteristic of different strains of mic It seems however that the postulate of "immune-response genes" is not nece sary to explain the differing responses to $S$. typhimurium in CBA and BALB, mice.

\section{SUMMARY}

The immune response to Salmonella typhimurium was investigated in CB. and BALB/C mice, by an arıthmetic Widal agglutination assay. High ant1- 
body titres were obtained in CBA and low titres in BALB/C mice after secondary immunisation.

A rabbit antiserum raised against $S$. typhimurium was tested for agglutinating activity after absorption with spleen- and lymph-node cells obtained from unimmunised CBA or BALB/C mice. BALB/C cells consistently removed more anti-S. typhimurium antibodies than did CBA cells, whilst the quantities of $\mathrm{Fc}$ receptor-bearing cells were found to be similar in both strains when measured by the erythrocyte-antibody rosette technique.

It is suggested BALB/C mice give a low antibody response because their cell-surface antigens crossreact to a greater degree with $S$. typhimurium than do CBA cell-surface antigens.

\section{REFERENCES}

Deacon, N. J. AND Ebringer, A. (1977). Cross-reactivity in the radioimmunoassay of ferritin with cells from high and low responder mice. Biochem. Soc. Trans., 5, 256.

Di Pauli, R. (1972). Genetics of the immune response. I. Differences in the specificity of antibodies to lipopolysaccharides among different strains of mice. J. Immunol., 109, 394.

Eastwood, A. (1927). Bacterial virulence and immunity. J. Hyg., Camb., 26, 235.

Ebringer, A. (1978). The link between genes and disease. New Scient., 79, 865.

Ebringer, A., Cowling, P., Ngwa Suh, N., James, D.C.O. and Ebringer, R.W. (1976). Crossreactivity between Klebsiella aerogenes species and B27 lymphocyte antigens as an aetiological factor in ankylosing spondylitis. In HLA and disease, edited by J. Dausset and

i A. Svejgaard, INSERM: Collague 58, 27. INSERM: Paris.

geringer, A. AND Davies, D. A. L. (1973). Crossreactivity between synthetic T, G A-L and in transplantation antigens in CBA mice. Nature (New Biol.), 241, 144.

RINGER, A., WELSH, J. AND YOUNG, C.R. (1976). Molecular mimicry as a pathogenetic mechanism in rheumatic fever. Heredity, Lond., 37, 455.

JoRER, P. A. AND SCHÜTZE, H. (1938). Genetical studies on immunity in mice. II. Correlation between antibody formation and resistance. J. Hyg., Camb., 38, 647.

GowEN, J. W. AND SChOTt, R. G. (1933). Genetic predisposition to Bacillus piliformis infection

Ii among mice. J. Hyg., Camb., 33, 370.

Hudson, L. and Hay, F. C. (1976). Practical immunology. Blackwell: Oxford, p. 38.

Kaplan, M. H., Meyeserian, M. AND Kushner, I. (1961). Immunologic studies of heart tissue.

IV. Serologic reactions with human heart tissue as revealed by immunofluorescent

(E methods; isoimmune, Wasserman and autoimmune reactions. J. exp. Med., 113, 17.

thufmann, F. (1954). Enterobacteriaceae. 2nd ed., Munksgaard: Copenhagen.

ABWIS, P. A. AND LOOMIS, D. (1928). Allergic irritability. IV. The capacity of guinea pigs to produce antibodies as affected by the inheritance and as related to familial resistance to

ig tuberculosis. J. exp. Med., 47, 437.

PCDevitt, H. O. and Sela, M. (1965). Genetic control of the antibody response. I.

ii Demonstration of determinant specific differences in response to synthetic polypeptide

$x$ antigens in two strains of inbred mice. J. exp. Med., 122, 517.

ACKIE, T. J. AND MCCARTNEY, J. E. (1953). Handbook of practical bacteriology, 9th ed.

Ji Livingstone: London, p. 275.

'Lant, J. AND GlynN, A. A. (1974). Natural resistance to Salmonella infection, delayed hypersensitivity and IR genes in different strains of mice. Nature, Lond., 248, 345.

'owleY, D. AND JENKIN, C. R. (1962). Antigenic cross-reaction between host and parasite as a possible cause of pathogenicity. Nature, Lond. 193, 151.

"AS, S. I. Roy, R. S. AND RoBSon, H. G. (1973). Endotoxin sensitivity of inbred mouse strains. Can. J. Microbiol., 19, 767. 